\title{
The Impact of Foreign Direct Investment on the Upgrading of Industrial Structure in the Yangtze River Delta
}

\author{
Yinan Zhu', Wei Wang ${ }^{2}$, * \\ ${ }^{1}$ School of Finance, Anhui University of Finance and Economics, Bengbu, Anhui, China \\ ${ }^{2}$ School of Economics, Anhui University of Finance and Economics, Bengbu, Anhui, China \\ *wangweiaufe@163.com
}

\begin{abstract}
Foreign direct investment and industrial upgrading are not only important driving forces to promote sustainable economic development, but also the objective needs of a country to deeply participate in international division of labor and competition. Firstly, this paper summarizes the literature at home and abroad, and puts forward the research problems and research ideas. Secondly, it makes a theoretical analysis of the impact of foreign direct investment on the upgrading of industrial structure. Thirdly, it analyzes the current situation of foreign direct investment and industrial structure upgrading. Finally, it analyzes the main problems of China's foreign direct investment affecting the upgrading of industrial structure, and puts forward targeted countermeasures and suggestions.
\end{abstract}

Keywords: Foreign direct investment, Yangtze River Delta, Industrial structure upgrading.

\section{Introduction}

Today's world is in a great change that has not been seen in a century, and China's economic development mode is also changing. In order to better cope with this situation, China needs to closely focus on building a new development pattern, improve factor utilization efficiency, comprehensively promote the reform and development of foreign investment cooperation, encourage and guide powerful and reputable Chinese enterprises to go global, actively participate in international competition and cooperation, and develop towards an intensive economy. In order to realize the transformation of China's domestic economy, we should vigorously promote the upgrading of industrial structure and promote the optimal development of various industries, so as to realize the stable, orderly and healthy development of foreign direct investment.

Foreign direct investment refers to the outflow of a country's international direct investment. It is one of the ways of international investment, which is conducive to the invested country to solve the financial difficulties and increase export trade. Nowadays, countries all over the world generally adopt the way of foreign direct investment to promote their own economic development and improve the industrial structure, so as to tend to a higher level of economic development. During the 13th Five Year Plan period, China's business development made remarkable achievements, and the stock of foreign direct investment doubled. In 2019, China's foreign direct investment was 136.91 billion US dollars, a year-on-year decrease of $4.3 \%$, second only to Japan's 226.65 billion US dollars. By the end of 2019, China's foreign direct investment stock had reached US \$2.2 trillion, second only to the United States and the Netherlands. China's outward direct investment flow ranks second in the world and its stock remains third in the world.

As one of the major urban agglomerations in the world, the Yangtze River Delta is one of the regions with the most active economic development, the highest degree of openness and the strongest innovation ability in China. As early as the early stage of reform and opening up, it was clearly proposed to plan the Yangtze River Delta as a unified economic zone. As China enters a new development stage, digital economy has gradually become the core force leading a new round of technological revolution and industrial change, providing a strong driving force for building a new development pattern. The Yangtze River Delta, composed of Shanghai, Jiangsu, Zhejiang and Anhui, is one of the regions with the most active economic development, the highest degree of openness and the strongest innovation ability in China. It plays an important role in China's reform and opening up. For example, the Yangtze River Delta has created nearly a quarter of China's total economic output with less than $4 \%$ of its land area; R \& $\mathrm{D}$ expenditure and the number of effective invention patents account for about $1 / 3$ of the country; Total imports and exports, foreign direct investment and foreign investment account for $37 \%, 39 \%$ and $29 \%$ of the country respectively. The strategy is one belt, one road, the coordinated development of Beijing, Tianjin and Hebei, the development of the Yangtze River economic belt, and the construction of the Guangdong, Hong Kong and Macau Bay area. It is interpreted by the outside world as China's key move to improve the spatial layout of reform and opening up in the new era.

In terms of economic aggregate, in 2020, the three provinces and one city in the Yangtze River Delta will achieve a total regional GDP of 24.5 trillion yuan, an increase of $3 \%$ over the previous year. The GDP of the Yangtze River delta accounts for $51.9 \%$ and $24.1 \%$ of the Yangtze River economic belt and the whole country respectively; The total retail sales of social consumer goods amounted to 9798.23 billion yuan, accounting for $30 \%$ of the country; The total import and export volume was 118543.37 , accounting for $36.9 \%$ of the national total.

Foreign direct investment and industrial upgrading are not only important driving forces to promote sustainable economic development, but also the objective needs of a country's deep participation in international division of labor 
and competition. Since the reform and opening up, with the rapid development of China's foreign direct investment, the domestic industry has also shown a trend of continuous upgrading in the same period. The relationship between the two is of great significance to China whose economy urgently needs to realize the transformation from traditional development mode to new development mode. The international financial crisis has triggered a global redistribution of resource elements and industries, and profound changes have taken place in the international competition pattern, which has created new opportunities for Chinese enterprises to "go global" and carry out foreign direct investment. This paper explores the internal relationship between the two from the perspective of provinces and cities in the Yangtze River Delta, puts forward research results with certain theoretical and practical value in order to promote the upgrading of industrial structure in the Yangtze River Delta, and puts forward relevant suggestions for better investment in provinces and cities in the Yangtze River Delta.

\section{Literature Review and Problem Raising}

With the deepening of opening up, the expansion of foreign investment scale and the gradual rise of international status, the research perspective of domestic and foreign scholars on foreign direct investment has gradually shifted from abroad to home. However, the domestic research on foreign direct investment and industrial structure upgrading is relatively late. First, it transitions from theoretical analysis to empirical analysis using relevant data. Finally, it combines the two and analyzes the development situation of our country by learning from foreign theoretical basis.

In terms of theoretical research, Wang Qi (2004) believes that foreign direct investment has obvious positive and negative effects on the industrial structure adjustment of investing countries [1]. Wang Lin (2006) believes that from an international perspective, both western developed countries and newly industrialized countries and regions in Asia regard foreign direct investment as an important way to improve the domestic (regional) industrial structure [2]. Hu Lijun (2013) studied the departure of industrial capital in Japan and the United States and found that the "flight" of capital led to the hollowing out of domestic industries and hindered the healthy development of the national economy [3]. Yuan Minglan (2015) believes that the impact of foreign direct investment on industrial structure adjustment is both direct and indirect, and expounds his personal view that foreign direct investment will lead to "industrial hollowing out" [4]. Zhang Jifeng (2015) believes that FDI can promote the upgrading of industrial structure in Jiangsu Province of China through industrial transfer effect and reverse technology spillover effect [5]. Xiang Zhengquan (2019) believes that although foreign investment is a shortcut for China's technology upgrading and industrial upgrading, countries and enterprises with technological advantages will not easily share core technologies with us, and we face layers of technical and non-technical barriers in technology acquisition [6]. Han Jiashu (2020) believes that, generally speaking, China's foreign direct investment has a significant positive impact on the upgrading of industrial structure. In the process of continuous foreign direct investment by domestic enterprises, industrial hollowing out should become the object of concern of the theoretical circles and the government [7]. Song Wenyan et al. (2021) believe that foreign direct investment and environmental regulation can significantly promote the upgrading of industrial structure, and the upgrading of industrial structure has obvious path dependence [8].

In terms of empirical research, Cui Yan et al. (2006) studied the economic situation of Japan and South Korea, and also came to the conclusion that foreign direct investment is conducive to the upgrading of industrial structure [9]. Xiang Benwu's (2009) research based on GMM model shows that from 2000 to 2007, the market scale of the host country is significantly negatively correlated with foreign direct investment, and the exchange rate level and bilateral trade are significantly positively correlated with foreign direct investment [10]. Wang Ying (2009) studied the time series data from 1985 to 2007 by selecting appropriate transmission variables and constructing appropriate measurement models, and believed that foreign direct investment mainly affects the adjustment of China's industrial structure through four paths: import structure, technological progress, employment structure and fixed capital [11]. Based on the data from 1990 to 2007, pan Ying et al. (2010) used cointegration theory and Granger causality to study and believed that FDI could not promote the upgrading of industrial structure in the short term, but could promote the upgrading of industrial structure in the long term [12]. Feng Zhengqiang et al. (2011) conducted relevant research using the same method. The results show that foreign direct investment can promote the upgrading of China's industrial structure, but the promotion effect is limited and there is a certain lag [13]. Zheng Lei (2012) analyzed the impact of China's investment in ASEAN on China's domestic industrial structure from 2005 to 2009 by using the grey correlation method. The results show that China's investment in ASEAN's financial industry, transportation, postal industry and manufacturing industry has played a strong role in promoting the upgrading of China's domestic industrial structure [14]. Zhang Fangfang (2019) constructed an econometric model from the perspective of rationalization and upgrading of industrial structure, based on the panel data of 23 provinces in China from 2003 to 2017, and analyzed the impact of foreign direct investment on the upgrading of industrial structure. The results show that foreign direct investment activities play a positive role in promoting the rationalization and upgrading of China's industrial structure. However, there are still differences in the effects of industrial structure among regions [15].

In general, domestic scholars have conducted extensive research on the upgrading effect of industrial structure of foreign direct investment, and there are many valuable achievements in both theoretical and empirical analysis. However, most of today's claims that foreign direct investment will lead to "industrial hollowing out" are generally expounded. Such claims are not fully based in China, because the causes and forms of industrial hollowing out are different and so on. Therefore, we need to further explore the knowledge content of this theory. Domestic scholars have different views on foreign direct investment and industrial structure upgrading, that is, whether foreign direct investment can promote industrial structure upgrading must be viewed dialectically. Different research objects, research ranges and research methods may have different results. Therefore, there is no unified conclusion on whether foreign direct investment can promote industrial structure upgrading. It needs to be analyzed on a case by case basis. 
This paper uses literature review, theoretical analysis and empirical analysis to explore the impact of foreign direct investment on the upgrading of industrial structure in the Yangtze River Delta. (1) Literature analysis. Previous studies are the basis of future research and discussion. We can see further on the shoulders of giants. Therefore, studying and analyzing the previous literature is the basis of thesis writing. By consulting relevant literature, the author combs the views on the role of foreign direct investment in the field of industrial structure upgrading, explores the relationship between the two, and understands the research results of researchers in different periods and regions on this issue. In addition, through the combination of reading a lot of literature and consulting data, the author realizes the current situation of the development of industrial structure in the Yangtze River Delta and has a clearer understanding of the theme. (2) Theoretical analysis. The theoretical basis is the basis of empirical research. Therefore, the author reads the literature and studies the relevant theories, has a certain understanding of the action mechanism of industrial structure upgrading, deepens the consolidation of previous knowledge and has a deeper understanding of the knowledge of economics in the process of theoretical learning. In addition, in terms of theoretical analysis, this paper studies the current situation of foreign direct investment and industrial structure upgrading, and deeply analyzes the relationship between them.

\section{Theoretical Analysis of the Impact of Foreign Direct Investment on Industrial Structure Upgrading}

\subsection{Theoretical Basis}

\subsubsection{International Production Compromise Theory}

With the wave of foreign capital export of a large number of multinational enterprises in developed countries, international production theory has become the focus of western scholars. In the early stage of theoretical research, economists mainly focused on the reasons for multinational corporations' overseas investment, overseas investment advantages and overseas investment location selection. Among them, Stephen Heimer's monopoly advantage theory is an excellent representative. He believes that multinational enterprises will pay attention to the possible "special costs" of overseas investment in addition to traditional production costs. Under the condition of incomplete market, the driving force for enterprises to invest abroad comes from some monopoly advantage of enterprises. Buckley puts forward that enterprises pursue profits, and the internalization advantage is the key factor for enterprises to prefer foreign investment compared with technology sales or transfer.

John Dunning integrates various theories, breaks through the limitations of previous studies, and discusses the influencing factors of foreign direct investment from three aspects. Among them, ownership advantage is the decisive basis for enterprises to make foreign direct investment, including tangible resources represented by natural endowment, labor force and capital and intangible resources represented by advanced technology, management experience and brand effect. In addition to the above advantageous resources, it should also include the ability of enterprises to allocate resources and dispatch global resources. In the imperfect market mechanism, how to use the enterprise advantage to solidify more profits in the enterprise and form the internal advantage is the key for the enterprise to be based on the international market. In addition, from the perspective of enterprise investment location, the main advantages are divided into the location advantages of the host country and the adverse location impact of the home country. The former mainly comes from the advantages of natural resources, loose tax environment or broad market space of the host country. The latter may be due to the comparative disadvantages of home countries such as international trade barriers and domestic factor price disadvantages. From the perspective of dynamic analysis of compromise theory, the three advantages of multinational enterprises will change with the change of production cycle. From the national level, although the country's economic strength, innovation level and financial capital will affect the scale of foreign capital output, the comparative advantage is the basis for the expansion of the scale of national foreign direct investment.

\subsubsection{Marginal Industry Expansion Theory}

After World War II, Japanese enterprises experienced a wave of large-scale external expansion. K. Koijma focuses on it to analyze the investment motivation of developing countries. By comparing the host country differences, enterprise type differences, technology gap and trade substitution effect of Japan US foreign direct investment, he found that Japan's foreign direct investment is mainly the transfer of "marginal industries" in a broad sense in the host countries with small technology gap. Transfer domestic industries with limited development, small and medium-sized enterprises squeezed by large enterprises or the production stage of a product to the host country, improve the labor productivity of the host country through "education effect", and also provide a basis for domestic trade development [16].

The theory of marginal industrial expansion puts forward that foreign direct investment is not only the output of financial funds, but also an all-round comprehensive transfer from human resources, capital, technology and management. The export of developed countries is mainly advanced enterprises with high technological differences with the host country. Through the local establishment of factories, technology export, product processing and manufacturing and direct sales, it will bring a "squeeze effect" to the export trade of the home country. On the basis of comparative cost, "marginal industry" selects the host country with small technology gap to build factories, and makes the low-cost host country resources return to the home country through sharing development achievements, non equity purchase and other forms. At the same time, the "demonstration effect" has also created more profits for the host country and increased the export of export products, which is conducive to improving the trade relations between the two countries.

\subsubsection{Reverse Technology Spillover Theory}

The reverse technology spillover effect mostly occurs in the investment behavior of multinational enterprises in developing countries to developed countries. This effect occurs because the investing countries learn and absorb the advanced technology and management experience of the host country in the investment process, and then apply the learned new technologies and methods to their domestic production practice by means of personnel mobility, so as to optimize the production of domestic related industries and promote the upgrading of domestic industries.

The mechanism of reverse technology spillover effect is as follows: the driving force of industrial structure upgrading is the improvement of total factor productivity, and this process depends on the advanced level of science and technology. 
Through a complex dynamic process, reverse technology spillover effect makes the company's behavior affect the industrial level, and then rise to the national level, so as to make the effect of investment in domestic biotechnology progress. Finally promote the optimization and upgrading of industrial structure.

Reverse technology transfer is opposite to the technology transfer from developed countries to developing countries. Reverse technology transfer is mainly realized through technology spillover, that is, imitating and innovating production technology and management methods. Through foreign investment, multinational enterprises in developing countries can establish good relations with foreign enterprises with advanced technology and achieve technological progress in comparison and learning. Therefore, foreign direct investment can affect domestic industry through reverse spillover effect, so as to optimize domestic industrial structure and realize industrial structure upgrading.

\subsection{Analysis on the Mechanism of Foreign Direct Investment Affecting Industrial Structure}

\subsubsection{Market Seeking FDI Impact Mechanism}

At present, international trade barriers still exist and even increase. In order to avoid various forms of tariff and nontariff barriers, many enterprises choose to invest in foreign markets and directly carry out production, sales and other activities in foreign markets, so as to broaden the market and promote the development of enterprises, which is marketseeking foreign direct investment. After considering the market scale and potential of the investing country, in order to avoid trade barriers and release domestic production capacity, market-seeking foreign direct investment is to establish a series of production departments and sales institutions in the investing country, which can effectively improve the market share and the profits of enterprises. In terms of influence mechanism, by avoiding export trade barriers, we can improve the export scale and export structure of enterprises' products, and finally promote the development of domestic economy and optimize domestic industrial structure.

\subsubsection{Impact Mechanism of Natural Resource Seeking FDI}

In order to obtain rich natural resources from abroad and lack or even scarce natural resources in China, natural resource-based foreign direct investment comes into being. The impact mechanism of seeking foreign direct investment in natural resources is that through foreign direct investment, the resources obtained abroad are sold back to China through legal channels, so as to maintain the long-term stable supply of domestic scarce resources, so as to improve China's industrial structure. Resource seeking foreign direct investment obtains the resources needed by enterprises by establishing resource development bases abroad. On the one hand, enterprises can break the resource bottleneck, reduce production costs and promote industrial development. On the other hand, they can give full play to the industrial correlation effect and drive the development of upstream and downstream enterprises, so as to promote the upgrading of domestic industrial structure (Pan Sukun, Yuan ran, 2014) [17]. In addition, with the development of foreign direct investment, enterprises will improve their production technology, so as to reduce their dependence on natural resources and rely more on "soft resources" such as science and technology, which is conducive to the upgrading of industrial structure (Bu Wei, Yi Qian, 2015) [18].

\subsubsection{Technology Oriented FDI Impact Mechanism}

In order to learn from foreign excellent and advanced technology, technology-oriented foreign direct investment arises. Its influence mechanism is that foreign direct investment enterprises avoid technical barriers through crossborder mergers and acquisitions, directly obtain the advanced technology of the investing country, and then bring the technology back to their own country, so as to improve their technical level and production efficiency. In addition, through technology seeking foreign investment direct investment, some domestic enterprises with strong international competitiveness begin to gain a firm foothold in the international market. In this process, the fierce competition in the international market will produce industrial competition effect, so as to drive the development of domestic related industries.

\section{Analysis on the Current Situation of Foreign Direct Investment and Industrial Structure Upgrading}

\subsection{Current Situation of Foreign Direct Investment}

According to the statistical bulletin of China's foreign direct investment in 2020 jointly issued by the Ministry of Commerce, the National Bureau of statistics and the State Administration of foreign exchange, China's foreign direct investment in 2020 mainly presents the following characteristics:

(1) Chinese enterprises' outward investment remained active on the whole. In 2020, China's outward direct investment reached US $\$ 153.71$ billion, a year-on-year increase of $12.3 \%$, ranking first in the world. At the end of 2020, China's outward direct investment stock reached US $\$ 2.58$ trillion, second to the United States (US \$8.13 trillion) and the Netherlands (US $\$ 3.8$ trillion) China's influence in global foreign direct investment continues to expand. The flow accounts for more than $10 \%$ of the world for five consecutive years, accounting for $20.2 \%$ in 2020 ; the stock accounts for $6.6 \%$, an increase of 0.2 percentage points over the previous year. China's two-way investment is basically the same in 2020, and the introduction and going out develop simultaneously.

(2) China's one belt and one road has been steadily increasing. By the end of 2020, China's 2.8 million domestic investors had set up 4.5000 foreign direct investment enterprises in 189 countries (regions), and over $80 \%$ countries (regions) had invested in China. At the end of the year, the total assets of overseas enterprises were 7 trillion and 900 billion US dollars. In the "one belt and one way", the total investment of overseas enterprises was 2. More than 11000 overseas enterprises have been established in the countries along the line. In 2020, the direct investment reached US $\$ 22.54$ billion, a year-on-year increase of $20.6 \%$, accounting for $14.7 \%$ of the flow in the same period; the year-end stock was US $\$ 2007.9$ billion, accounting for $7.8 \%$ of the total stock. From 2013 to 2020, China's cumulative direct investment in the countries along the line was US $\$ 139.85$ billion.

(3) The investment field is becoming more and more extensive and the structure is constantly optimized. In 2020, 
China's foreign direct investment covered 18 industry categories of the national economy. Nearly $70 \%$ of the investment went to leasing and business services, manufacturing, wholesale and retail, and finance, and the flow of the four industries exceeded us $\$ 10$ billion. By the end of $2020,80 \%$ of China's foreign direct investment stock was concentrated in the service industry, mainly in leasing and retail Business services, wholesale and retail, information transmission / software and information technology services, finance, real estate, transportation / warehousing and postal services.

(4) The foreign investment of the non-public economy and the holding entities of the public economy went hand in hand. In 2020, among China's foreign non-financial investment flows, the foreign investment of domestic investors controlled by the non-public economy was US $\$ 67.16$ billion, accounting for $50.1 \%$, with a year-on-year increase of $14.1 \%$; the foreign investment of domestic investors controlled by the public economy was US $\$ 66.89$ billion, accounting for $49.9 \%$, with a year-on-year increase of $15.1 \%$.

(5) Mutual benefit and win-win results have been highlighted and common development has been achieved. In 2020, overseas Chinese funded enterprises paid a total of US $\$ 44.5$ billion in taxes to the countries and regions where they invested, employing 2.218 million foreign employees, accounting for $60.6 \%$ of the total number of employees of overseas enterprises. Foreign investment led to the export of Chinese goods of US $\$ 173.7$ billion, accounting for $6.7 \%$ of China's total export value. Overseas Chinese funded enterprises achieved sales revenue in the same year. In the current world economic development, China's foreign direct investment shows an increasingly strong growth momentum both in terms of total amount and scope. The development of foreign economy is not only an objective requirement of the trend of economic globalization, but also an inevitable trend of China's economic development.

\subsection{Current Situation of Industrial Structure Upgrading}

There are two elements in the transformation of industrial structure: one is transfer and the other is upgrading. The socalled transfer is to transfer a large number of low-end laborintensive industries with excess capacity to other regions; the so-called upgrading is to replace the above industries with capital intensive industries supported by high technology.

Since the beginning of the 21 st century, China's industrial structure and the employment structure of three industries have been continuously optimized. The growth of the primary industry is relatively slow, the growth of the secondary industry is rapid, and the tertiary industry has broken through the single development pattern dominated by commerce and catering, accelerating the development of finance, insurance, $\mathrm{R} \& \mathrm{D}$ consulting and other industries. At the same time, the proportion of employment in the primary industry has decreased significantly, and the proportion of employment in the secondary industry has increased The growth rate of the employment proportion of the tertiary industry is slower than that of the secondary industry. Generally speaking, China's industrial structure has been continuously optimized on the basis of maintaining the second and third type. However, many problems still exist when analyzing China's current industrial structure and employment structure from a static or dynamic perspective. The development of China's industrial structure has reached a bottleneck period, the restriction of national policies is urgently needed.

China's one belt, one road to China's development, is to achieve the goal of "transforming China's Middle Income Trap" and finally to become a developed country. In theory, there is only one way to accomplish the transformation of industrial structure. Therefore, in the face of this arduous task, China will make use of the core values and objectives of the "one belt and one way" strategy to help China finally achieve its goal. "

\section{Problems and Countermeasures of Foreign Direct Investment Affecting Industrial Structure Upgrading}

\subsection{Existing Problems}

(1) Foreign direct investment. Although China's foreign direct investment has developed rapidly in recent years, there are still many problems on the whole: the overall scale of foreign direct investment is obviously small, so China's foreign direct investment is still in its infancy. The scale of foreign investment of Chinese enterprises is relatively small. The technical content of investment projects is not high. The regional structure of enterprises' foreign investment is not reasonable. From the perspective of the overall overseas investment layout, the investment in developing countries and regions is still obviously low, which affects the further expansion of China's foreign investment market. The efficiency of enterprises' foreign investment needs to be further improved. Foreign investment lacks effective national macro guidance.

(2) Industrial structure upgrading. At present, the current situation and existing problems of China's industrial structure are mainly reflected in the following aspects: the industrial structure and employment structure are seriously distorted, a large number of labor force is stranded in agriculture, and the output value structure and employment structure of the three industries are seriously misplaced. The ability of the secondary industry to absorb employment has declined. The position of new industries with high growth is not prominent. The lack of pillar industries with high growth and strong driving force is an important reason for weak economic growth. The development of tertiary industry lags behind. The development of service industry lags behind the actual level of economic development. Sustainable development faces great pressure.

\subsection{Countermeasures and Suggestions}

(1) Increase market seeking and efficiency seeking OFDI and promote the generation of reverse technology spillovers. The research shows that reverse technology spillover of foreign direct investment and technology spillover of import trade can significantly improve regional innovation ability. In foreign direct investment, it is necessary to formulate foreign direct investment policies according to the characteristics of the technological gap between the region and the host country. At the same time, increase import trade and give full play to the role of import trade technology spillover in promoting the improvement of regional innovation ability; Expand regional $\mathrm{R} \& \mathrm{D}$ investment and improve the technological innovation ability of enterprises. Strengthen policy support for Chinese enterprises OFDI's investment in developed economies (regions). In terms of technology, knowledge accumulation and management, developed countries (regions) are still leading China as a whole, and also dominate the current 
industrial division of labor in the world. Through green space investment or enterprise $\mathrm{M} \& \mathrm{~A}$, it is helpful to obtain industry-leading technology and experience and shorten R \& D time and development cost.

(2) Pay attention to the education and training of talents and turn China's huge labor force into human capital. Increase investment in higher education, encourage and support the combination of industry, University and research, accelerate the cultivation of Applied Talents in practice, and improve the overall improvement of human resources from quantity to quality. From the micro point of view, it is conducive to the improvement of enterprise technology R \& D level, and from the macro point of view, it is a necessary condition for national industrial upgrading. Accelerating the improvement of talent training mechanism will contribute to the optimization and upgrading of domestic industrial structure.

(3) Enterprises are encouraged to adopt independent research and development to improve technology. The technology gap between Shanghai and Jiangsu Province and the host country is small. It is difficult to improve the regional technology level through the technology spilled over from the foreign direct investment channel. The two places have a solid industrial foundation and strong scientific and technological R \& D capacity, which can encourage the enterprises in the region to improve the technology by means of independent research and development, so as to improve the regional innovation ability.

(4) Correctly select countries for direct investment. Zhejiang, Hubei and Chongqing can choose to invest directly in developed countries because of the small difference between the technology gap and the threshold value; In Jiangxi, Anhui, Hunan, Sichuan, Guizhou and Yunnan provinces, due to the large difference between the technology gap and the threshold value, enterprises can choose to invest in medium-sized developed countries in order to better undertake and absorb the technology spillover from foreign direct investment channels.

(5) Focus on acquiring knowledge and advanced skills. Overseas direct investment in the manufacturing industry in the Yangtze River Delta will have a linkage effect in China and have a positive impact on the operation and development of enterprises in China, such as obtaining policy support, obtaining financial resources, consolidating the domestic market, etc. From the theoretical analysis of overseas investment in developing countries, manufacturing enterprises in the Yangtze River Delta should pay attention to acquiring knowledge and advanced skills and establishing a mature external network, so as to truly transform overseas resources into their own competitive advantages.

\section{References}

[1] Wang Qi. Effect of foreign direct investment on industrial structure adjustment of investing countries and its transmission mechanism [J]. International trade issues, 2004 (05): 3-7.

[2] Wang Lin. Research on China's foreign direct investment and industrial structure adjustment [J]. Value engineering, 2006, 25 (6): $1-3$.
[3] Hu Lijun, Xue Fugen, Wang Yu. Mechanism and governance of industrial hollowing out in the post industrialization stage -Taking Japan and the United States as examples [J]. China industrial economy, 2013 (08): 122-134.

[4] Yuan Minglan. Impact mechanism of foreign direct investment on industrial structure adjustment [J]. Labor security world, 2015 (21): 46-47.

[5] Zhang Jifeng, Xuan Changyong. Research on Jiangsu's foreign direct investment promoting industrial upgrading under the new normal [J]. Jiangsu social sciences, 2015 (5): 259-265.

[6] Xiang Zhengquan. The impact of foreign direct investment on China's industrial structure adjustment [J]. Modern commerce and industry, 2019, 40 (9): 5-6.

[7] Han Jiashu. The impact of foreign direct investment on the upgrading of China's industrial structure $[\mathrm{J}]$. China's collective economy, 2020 (16): 19-21.

[8] Song Wenyan, Han Weihui. Environmental mechanism, foreign direct investment and Industrial Structure Upgrading - Also on the threshold effect of heterogeneous environmental regulation[J]. Contemporary economic science, 2021,43 (02): 109-122.

[9] Cui Yan, Zang Xin. Empirical analysis on the relationship between Japanese foreign direct investment and industrial structure [J]. Journal of Nanjing University of finance and economics, 2006 (2): 41-45.

[10] Xiang Benwu. Empirical Study on the characteristics of host countries and China's foreign direct investment [J]. Quantitative economy, technical economy, quantitative economy, technical economy, 2009,26 (07): 33-46.

[11] Wang Ying. Empirical analysis on the impact of foreign direct investment on industrial structure adjustment $[\mathrm{J}]$. Audit and economic research, 2009, 24 (4): 85-89.

[12] Pan Ying, Liu Huihui. Empirical Study on the relationship between China's foreign direct investment and industrial structure upgrading $[\mathrm{J}]$. Statistics and decision making, 2010 (2): 102-104.

[13] Feng Zhengqiang, Zhang Yan. Empirical study on the relationship between China's foreign direct investment and industrial structure adjustment [J]. Economic Research Guide, 2011 (22): 147-148.

[14] Zheng Lei. Foreign direct investment and upgrading of industrial structure -- Analysis based on industry data of China's direct investment in ASEAN [J]. Economic issues, 2012 (02): 47-50.

[15] Zhang Fangfang. Research on the impact of China's foreign direct investment on the upgrading of industrial structure in the new era [J]. China market, 2019 (23): 75-78.

[16] Xiao Daoqing. Foreign trade theory [M]. Translated by Zhou Baolian. Tianjin: Nankai University Press, 1987.

[17] Pan Sukun, Yuan Ran. Theoretical and empirical research on OFDI promoting industrial upgrading with different investment motives [J]. Economist, 2014 (09): 69-76.

[18] Bu Wei, Yi Qian. Study on the impact of OFDI on China's industrial upgrading [J]. Macroeconomic research, 2015 (10): 54-61. 